\title{
Analysis of experimental results of a Pressurized Solid Oxide Fuel Cell System simulating a Hybrid Power Plant
}

\author{
Matthias Metten ${ }^{1, *}$, Marius Tomberg ${ }^{1}$, Marc P. Heddrich ${ }^{1}$, and $K$. Andreas Friedrich ${ }^{1}$ \\ ${ }^{1}$ German Aerospace Center (DLR), Institute of Engineering Thermodynamics, Electrochemical \\ Energy Technology, Pfaffenwaldring 38-40, 70569 Stuttgart, Germany
}

\begin{abstract}
The low-carbon economy of the future needs low consumption of fossil and high quality renewable based fuels. This requires high efficiencies, good part-load performance and fuel flexibility. A very promising concept to achieve that is the combination of solid oxide fuel cells (SOFC) with a gas turbine (GT) in a pressurized hybrid power plant. However, experimental data for such SOFC/GT systems are rare. Thus, the DLR built a test rig to analyse such a system with $30 \mathrm{~kW}$ electrical output. A $30 \mathrm{~kW}$ SOFC module is used under pressurized conditions with components that emulate the GT. Commercially available stacks and state of the art peripheral components are installed. These include e.g. a hot anode off-gas recirculation blower, a steam reformer and recuperator. The system was put into operation and is used to experimentally analyse its operational behaviour. This publication will give insights about the current status of the experimental work. It will outline the basic SOFC/GT process, the implementation within the installed SOFC system and the degrees of freedom in comparison to a coupled system. Experimental results are shown and the impact of main parameters is analysed.
\end{abstract}

\section{Introduction}

The targeted low-carbon economy of the future requires a low consumption of fossil and high value renewable based fuels to keep down increasing operational costs. For that, high efficiencies, good part load performance and a high fuel flexibility is required. A very promising concept to achieve that is the combination of solid oxide fuel cells (SOFC) with a gas turbine (GT) in a pressurized hybrid power plant [1]. Such a system was recently demonstrated by Mitsubishi-Hitachi Power Systems (MHPS) with an electrical power output of $250 \mathrm{~kW}$ that runs on natural gas [2]. It is currently being tested in field trials in Japan, two systems are commercially sold [3, 4] and a scale-up to $1 \mathrm{MW}$ is in progress [5]. In addition LG Electronics (LG) built a $250 \mathrm{~kW}$ demonstrator [6] and operated it for about 2000 hours [7].

However, experimental data for such $\mathrm{SOFC/GT}$ systems are rare and therefore the German Aerospace Center (DLR) is planning to build demonstrator with $30 \mathrm{~kW}$ electrical output and an estimated efficiency of about $66 \%$-LHV [8]. The main goal is to prove the

\footnotetext{
${ }^{*}$ Corresponding author: Matthias.Metten@dlr.de
} 
underlying concept, to analyze its strength and weaknesses and to gather data for its use in e.g. modular power generation. Detailed heat loss simulations show an efficiency of 60 to $64 \%$-LHV [9].

\section{Method and basic system}

In comparison to the systems of MHPS and LG planar cells are used. In a first step, two separate test rigs were built. The first one uses a real GT and components that emulate the SOFC (Institute of Combustion Technology). The second one, object of the presented study, uses a $30 \mathrm{~kW}$ SOFC module under pressurized conditions with components that emulate the GT (Institute of Engineering Thermodynamics). This pressurized solid oxide fuel cell system (pSOFC) uses commercially available planar stacks with electrolyte supported cells (ESC) and state of the art balance of plant (BOP) components. It includes a hot anode off-gas recirculation blower, a steam reformer and recuperator. Both systems were put into operation and are now being used to experimentally analyze their operational behavior. In a second step the SOFC and GT shall be combined.

A short overview of the basic SOFC/GT system is shown in Fig. 1. Air is compressed via the compressor (COMP) of the GT, exhaust heat recuperated in a heat exchanger (RECU) and used in the SOFC cathode for oxidation and cooling purposes. In parallel the fuel is desulfurized (DESUL), mixed with recirculated anode off-gas and supplied to the anode of the SOFC after passing a catalytic steam reformer (REF). The recirculate delivers the needed amount of steam. After electrochemical oxidation and generation of electricity in the SOFC a part of the anode off-gas is recirculated via a highly flexible hot gas recirculation blower (REC) into the inlet of the reformer. The remaining fuel is burned (BURN) with the cathode exhaust air. A part of the energy is afterwards used via the turbine to run the compressor and generates additional electricity. Exhaust heat is used via the previously described recuperator.

\section{Experimental Setup}

The pSOFC is shown in Fig. 2. Here, the compressor is simulated via the use of pressurized air from the infrastructure and an electrical heater (COMP SIM). The latter one is used to simulate the increase of temperature by the compression of the real GT. Besides this, the temperature and the gas flow within the pressure vessel can be varied to analyze their influence on heat losses of the system and its performance. The cathode air is directly preheated in a heat exchanger (RECU SIM) that simulates the recuperator. The heat is generated by a standard natural gas burner (BURN). Its temperature can be varied to investigate the effects of heat losses, changing turbine exhaust temperatures or thermal gradients. In addition to that, pressurized air is used to cool the wires, power cables and current collectors in the sensors compartment below the SOFC. The fuel can be mixed from natural gas, hydrogen, nitrogen and carbon dioxide. The pressure is controlled via a valve at the outlet of the pressure vessel and a second one at the outlet of the sensors compartment. Remaining fuel is oxidized in an oxidation catalyst (OXI CAT) before the exhaust exits to the ambient. 


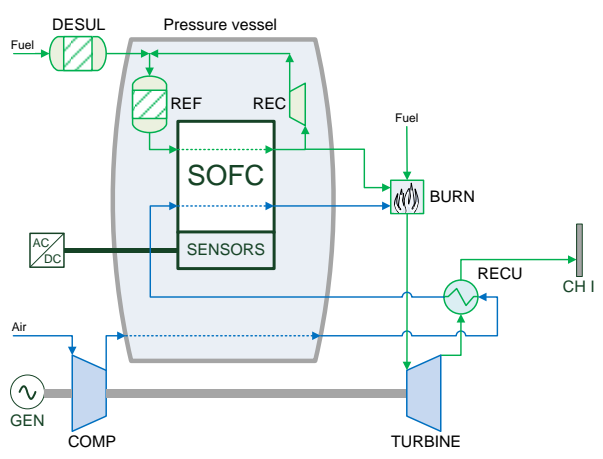

Fig. 1. Process flow diagram of the basic hybrid power plant

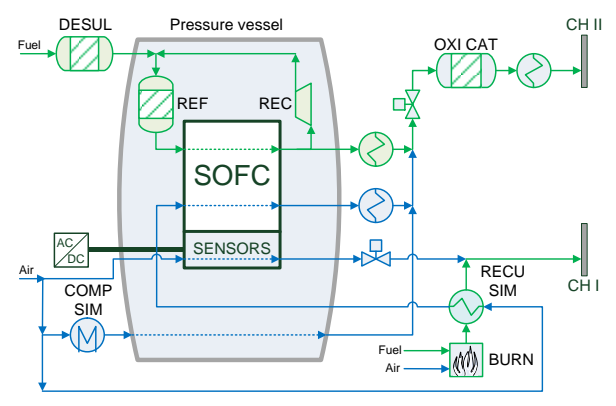

Fig. 2. Process flow diagram of the pSOFC

\section{Results and Outlook}

First experimental results show that about $45 \%$ of the chemical energy (LHV) of hydrogen is transformed to electricity at an overall fuel utilization of $70 \%$ and a power output of 15 to $20 \mathrm{~kW}_{\mathrm{el}}$. With a fuel mixture of $50 \%$ chemical energy from natural gas and the rest from hydrogen the efficiency is in the same range. These results show already an acceptable efficiency without optimizing for it. In the next steps, higher fuel utilizations, an optimized temperature maximizing strategy and higher power outputs are planned.

An important effect within the system is the heat loss. E.g. the heat loss via the sensors compartment is in the range of $1,6 \mathrm{~kW}$ depending on the operating temperature of the SOFC. The heat lost via the externally cooled hot air recirculation blower is in the range of $2,5 \mathrm{~kW}$. Hence, optimizing strategies such as higher allowed sensor compartment temperatures and a reduction of the heat transfer within the recirculation blower could increase the efficiency of the system. Especially the heat within the recirculated anode offgas is needed to run the endothermic steam reforming reaction in the reformer. Lower heat losses would therefore lead to lower recirculation ratios which are primarily needed to achieve high anode inlet temperatures. Consequently the power needed to run the recirculation blower could be decreased and the overall efficiency could be increased.

\section{Acknowledgements}

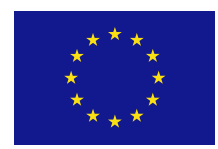

This project has received funding from the European Union's Horizon 2020 research and innovation program under grant agreement No 641073 (www.bio-hypp.eu).

Furthermore, the support from the German Federal Ministry of Economic Affairs and Energy for the project "DemoHydra" is gratefully acknowledged. (Support code: 03ET6032). 


\section{Nomenclature}

\begin{tabular}{|c|c|c|c|}
\hline BOP & balance of plant & LHV & lower heating value \\
\hline BURN & burning chamber (Fig. 1) & MHPS & Mitsubishi-Hitachi Power \\
\hline BURN & natural gas Burner (Fig. 2) & & Systems \\
\hline $\mathrm{CH} \mathrm{I}$ & Chimney 1 & OXI CAT & oxidation catalyst \\
\hline CH II & Chimney 2 & pSOFC & pressurized solid oxide \\
\hline COMP & compressor & & fuel cell system \\
\hline COMP SIM & compressor simulator & REC & recirculation blower \\
\hline DESUL & desulfurization & RECU & recuperator \\
\hline DLR & German Aerospace Center & RECU SIM & recuperator simulator \\
\hline GT & gas turbine & REF & catalytic steam reformer \\
\hline LG & LG Electronics & SOFC & solid oxide fuel cell \\
\hline
\end{tabular}

\section{References}

1. L. van Biert, T. Woudstra, M. Godjevac, K. Visser and P. V. Aravind, "모 thermodynamic comparison of solid oxide fuel cell-combined cycles", J. Pow. Sour., 397, 382-369, (2018).

2. MHPS, LTD., "Demonstration Testing Started of SOFC-MGT Hybrid Power Generation System, Toward Commercial Launch for Business and Industrial Uses" (21.09.2016). [Online]. Available: https://www.mhps.com/news/20160921.html. [Accessed 28.02.2019].

3. MHPS, LTD., "MHPS Receives First Order for Integrated Fuel Cell and Gas Turbine Hybrid Power Generation System” (31.01.2018). [Online]. Available: https://www.mhps.com/news/20180131.html. [Accessed 14.01.2019].

4. MHPS, LTD., "MHPS Receives Order from Hazama Ando Corp. for "MEGAMIE" Hybrid Power Generation System" (25.04.2019). [Online]. Available: https://www.mhps.com/news/20190425.html. [Accessed 30.04.2019].

5. MHPS, LTD., "Fuel Cells | Products | MITSUBISHIHITACHI POWER SYSTEMS, LTD," 2018.11.19. [Online]. Available: https://www.mhps.com/products/ sofc/index.html. [Accessed 01.03.2019].

6. D. Crispin, "19th SOFC Annual Workshop" 13.06.2018. [Online]. Available: https://netl.doe.gov/sites/default/files/netl-file/FE2-2018-June-13-19th-DOE-AnnualWorkshop-LGFCS-Presentation-Final.pdf. [Accessed 28.02.2019].

7. J. Funk, "AP News," 11.12.2018. [Online]. Available: https://www.apnews.com/ 154ebba5a87d49a29f0fcc1467fae9b5. [Accessed 29.04.2019].

8. M. Henke, M. Steilen, C. Schnegelberger, M. Riedel, M. Hohloch, S. Bucheler, M. Herbst, A. Huber, J. Kallo and K. A. Friedrich, "Construction of a 30kW SOFC Gas Turbine Hybrid Power Plant" ECST, 68, 1, 85-88, (2015).

9. M. Steilen, C. Saletti, M. P. Heddrich and K. A. Friedrich, "Analysis of the influence of heat transfer on the stationary operation and performance of a solid oxide fuel cell/gas turbine hybrid power plant", J. Appn. Ergy., 211, 479-491, (2018). 